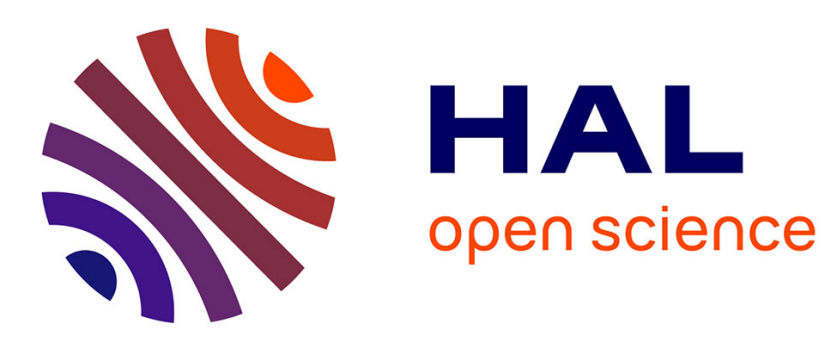

\title{
The oxidized form of glutathione
}

\author{
Christian Jelsch, Claude Didierjean
}

\section{To cite this version:}

Christian Jelsch, Claude Didierjean. The oxidized form of glutathione. Acta Crystallographica Section C: Crystal Structure Communications [1968-2013], 1999, C55, Part 9, pp.1538-1540. 10.1107/S0108270199007039 . hal-01710290

\section{HAL Id: hal-01710290 \\ https://hal.science/hal-01710290}

Submitted on 15 Feb 2018

HAL is a multi-disciplinary open access archive for the deposit and dissemination of scientific research documents, whether they are published or not. The documents may come from teaching and research institutions in France or abroad, or from public or private research centers.
L'archive ouverte pluridisciplinaire HAL, est destinée au dépôt et à la diffusion de documents scientifiques de niveau recherche, publiés ou non, émanant des établissements d'enseignement et de recherche français ou étrangers, des laboratoires publics ou privés. 
Data collection: DIF4 (Stoe \& Cie, 1992a). Cell refinement: DIF4. Data reduction: REDU4 (Stoe \& Cie, 1992b). Program(s) used to solve structure: SHELXS97 (Sheldrick, 1997a). Program(s) used to refine structure: SHELXL97 (Sheldrick, 1997b). Molecular graphics: XP in SHELXTL/PC (Sheldrick, 1990). Software used to prepare material for publication: SHELXL97.

The authors thank the EPSRC and Zeneca Specialties for funding and Dr Neil Feeder for assistance.

Supplementary data for this paper are available from the IUCr electronic archives (Reference: CF1307). Services for accessing these data are described at the back of the journal.

\section{References}

Allen, F. H., Kennard, O., Watson, D. G., Brammer, L., Orpen, A. G. \& Taylor, R. (1987). J. Chem. Soc. Perkin Trans. 2, pp. S1-19.

Barnett, B. L., Kretschmar, H. C. \& Hartman, F. A. (1977). Inorg. Chem. 16, 1834-1838.

Jones, R. A. \& Katritsky, A. R. (1960). J. Chem. Soc. pp. 2937-2942.

Paulus, W. (1993). Microbicides for the Protection of Materials: A Handbook. London: Chapman and Hall.

Robinson, M. A. (1964). J. Inorg. Nucl. Chem. 26, 1277-1281.

Sheldrick, G. M. (1990). SHELXTLPC. Version 4.1. Siemens Analytical Instruments Inc., Madison, Wisconsin, USA.

Sheldrick, G. M. (1997a). SHELXS97. Program for the Solution of Crystal Structures. University of Göttingen, Germany.

Sheldrick, G. M. (1997b). SHELXL97. Program for the Refinement of Crystal Structures. University of Göttingen. Germany.

Stoe \& Cie (1992a). DIF4. Diffractometer Control Program. Version 7.09/DOS. Stoe \& Cie, Darmstadt, Germany

Stoe \& Cie (1992b). REDU4. Data Reduction Program. Version 7.03. Stoe \& Cie, Darmstadt, Germany.

Xu, Y.-J., Kang, B.-S., Chen, X.-T. \& Huang, L.-R. (1995). Acta Cryst. C51, 370-374.

Acta Cryst. (1999). C55, 1538-1540

\section{The oxidized form of glutathione}

\section{Christian Jelsch and Claude Didiersean}

Laboratoire de Cristallographie et Modélisation des Matériaux Minéraux et Biologiques ( $L C M^{3} B$ ), UPRESA $n^{\circ}$ 7036, Université Henri Poincaré, Nancy 1, Faculté des Sciences, BP 239, 54506 Vandoeuvre lès Nancy CEDEX,

France.E-mail: jelsch@lcm 3 b.u-nancy.fr

(Received 13 August 1998; accepted 19 Mar 1999)

\footnotetext{
Abstract

The crystal structure of the oxidized form of the tripeptide glutathione ( $\gamma$-L-glutamyl-L-cystylglycine octahydrate, $\mathrm{C}_{20} \mathrm{H}_{32} \mathrm{~N}_{6} \mathrm{O}_{12} \mathrm{~S}_{2} \cdot 8 \mathrm{H}_{2} \mathrm{O}$ ) has been determined at $100 \mathrm{~K}$. The molecule was crystallized from aqueous solution in the presence of the precipitating agent polyethylene glycol by the vapor-diffusion method, which is commonly used in protein crystallization. The space group is $P 2,2,2$ and the molecule contains a crystallographic twofold symmetry axis through the middle of the disulfide bridge. There are four water molecules per tripeptide, two of which are disordered. The $S-S$ and $S-C$ bond lengths are 2.0387 (9) and 1.8098 (19) $\AA$, respectively, and the $\mathrm{C}-\mathrm{S}-\mathrm{S}$ bond angle is $105.03(6)^{\circ}$.

\section{Comment}

The reduced form of glutathione (GSH) is present in animal cells and has various biological functions, notably the reduction of toxic peroxides. The $\mathrm{SH}$ group can be oxidized to form a disulfide bridge: $2 \mathrm{GSH} \rightarrow$ GSSG $+2[\mathrm{H}]$ (Metzler, 1977). The crystal structure of the reduced form of glutathione has been determined by Wright (1958) and redetermined by Görbitz (1987). The tripeptide glutathione ( $\gamma$-L-glutamyl-L-cystylglycine) has a special peptide linkage as the glutamic acid residue is attached to the cystine residue through the $\gamma$-carboxyl group rather than through the $\alpha$-carboxyl group.

The structure of GSSG $8 \mathrm{H}_{2} \mathrm{O}$ has been determined using orthorhombic crystals of space group $P 2_{1} 2,2$. The crystal structure contains a crystallographic

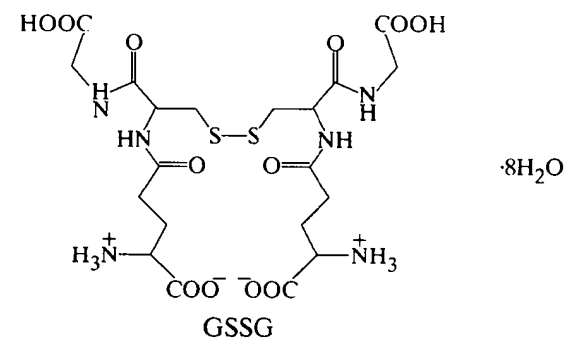

twofold symmetry axis through the center of the disulfide bridge (Fig. 1). There are four water molecules in the asymmetric unit and two of them are disordered. The stereochemical data for the side chain of the cystine residue and the disulfide bridge are given in Table 1. The glutathione peptide has a left-handed disulfide chirality $\left[\mathrm{C}-\mathrm{S}-\mathrm{S}-\mathrm{C}=-97.0(4)^{\circ}\right]$, unlike cystine in the tetragonal (Chaney \& Steinrauf, 1974) and hexagonal (Oughton \& Harrison, 1959) crystal forms. The disulfide bridge length is 2.0387 (9) $A$, which is the same, within experimental error, as the length found in tetragonal $(2.043 \AA)$ and hexagonal $(2.032 \AA)$ cystine crystals, and the mean value of $2.029 \AA$ for 46 disulfides found in small molecules (Allen et al., 1987). The $\mathrm{C}-\mathrm{S}$ distance of 1.8098 (19) $\AA$ agrees also with the average value of $1.815 \AA$ given in International Tables for Crystallography (Vol. C, 1992). The $\varphi, \psi$ and $\omega$ 


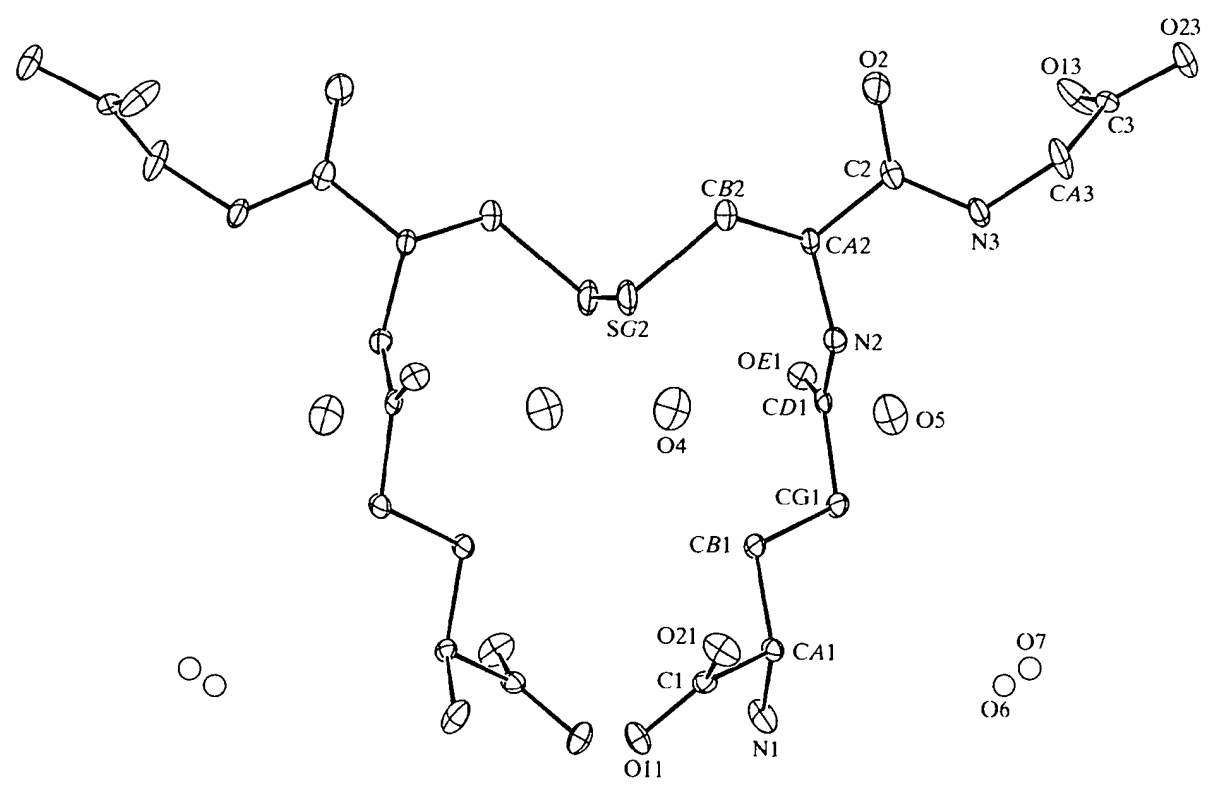

Fig. 1. Representation of the molecular structure and atom-numbering scheme of GSSG and the water molecules. The displacement ellipsoids are shown at the $50 \%$ probability level. The two disordered water molecules are shown as small circles corresponding to the sites with the highest occupancy factor.

dihedral angles of the main peptide chain are given in Table 1.

The glutathione molecule has two carboxyl groups (Fig. 1). An $\mathrm{H}$ atom (H23) was localized in the vicinity of the carboxyl $\mathrm{O} 23$ atom by difference Fourier synthesis. Moreover, the $\mathrm{C} 3-\mathrm{O} 23$ bond length is $1.323(2) \AA$, which is clearly longer compared with the other carboxyl $\mathrm{C}-\mathrm{O}$ distances (Table 1). The carboxyl moiety on the glycyl residue is thus neutral, whereas on the glutamyl residue it is negatively charged. The $\mathrm{H}$ atom protonating the $\mathrm{O} 23$ oxygen is involved in a hydrogen bond with the carboxylate group of a neighboring molecule (Table 2).

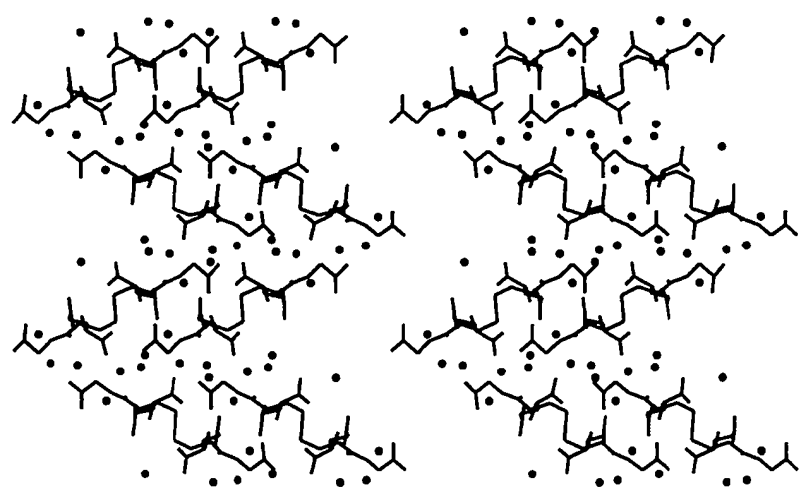

Fig. 2. A stereographic view of the GSSG crystal packing, with $a$ horizontal and $b$ vertical. Water molecules are represented as black dots and only one site for each of the two disordered water molecules is shown.
The amine group of the glutamyl residue is clearly positively charged, as the three $\mathrm{H}$ atoms are visible in the electron-density maps. The two amine and two carboxylate groups present in the GSSG peptide form two intramolecular head-to-tail salt bridges (N1$\mathrm{H} 21$... O11) related by the diad axis. The amine moiety is also hydrogen bonded to the carbonyl $\mathrm{O} 2$ atom and to the disordered 06 water molecule (Table 2).

Two water molecules out of the four present in the asymmetric unit are disordered; this might be ascribed to the two solvent-channel networks in the GSSG $8 \mathrm{H}_{2} \mathrm{O}$ crystals. The most visible in Fig. 2 is a straight channel parallel to the $a$ axis, while the second one is a zigzag in the direction of the $b$ axis. The presence of these channels explains why the crystals dry out after a few days of exposure to air.

\section{Experimental}

GSSG was purchased from SIGMA (St Louis, USA). Slow evaporation of water solutions of GSSG led to a viscous liquid without the formation of crystals. However, it was possible to obtain crystals in 3-4 d in the presence of the precipitating agent polyethylene glycol by vapor diffusion in a sealed volume at room temperature. The glutathione peptide was dissolved in an aqueous solution of polyethylene glycol (MW 8000 ) and drops of this solution were equilibrated against a concentrated solution of the polymer. This result shows that crystallization techniques employed for proteins can also be fruitful in the case of peptides. Since the crystals lose their water content over a period of a few days on exposure to air, 
they were placed, after removal of the surrounding liquid, in a sealed quartz capillary. To avoid crystal drying, the capillary contained, on the side, a small amount of mother liquor. The stream of liquid nitrogen at $100 \mathrm{~K}$, surrounded by a stream of dry air, was produced by an Oxford Cryosystems cooler ( 600 series; Cosier \& Glazer, 1986). The diffractometer system was in a closed volume and no ice formation was observed on the capillary.

\section{Crystal data}

$\mathrm{C}_{20} \mathrm{H}_{32} \mathrm{~N}_{6} \mathrm{O}_{12} \mathrm{~S}_{2} \cdot 8 \mathrm{H}_{2} \mathrm{O}$

$M_{r}=756.76$

Orthorhombic

$P 2{ }_{1} 2_{1} 2$

$a=9.4742$ (2) $\AA$

$b=16.6161$ (4) $\AA$

$c=10.8918(7) \AA$

$V=1714.63(12) \AA^{3}$

$Z=2$

$D_{x}=1.466 \mathrm{Mg} \mathrm{m}^{-3}$

$D_{m}$ not measured

\section{Data collection}

Nonius Kappa-CCD diffractometer

Oscillation scans

Absorption correction: none 23453 measured reflections 3430 independent reflcctions

\section{Refinement}

Refinement on $F^{2}$

$R\left[F^{2}>2 \sigma\left(F^{2}\right)\right]=0.038$

$w R\left(F^{2}\right)=0.100$

$S=1.108$

3430 reflections

261 parameters

$\mathrm{H}$ atoms treated by a mixture of independent and constrained refinement
$\mathrm{Ag} K \alpha$ radiation

$\lambda=0.56087 \AA$

Cell parameters from 57 reflections

$\theta=3-22^{\circ}$

$\mu=0.134 \mathrm{~mm}^{-1}$

$T=100(2) \mathrm{K}$

Rectangular prism

$0.30 \times 0.22 \times 0.20 \mathrm{~mm}$

Colorless

3263 reflections with

$$
I>2 \sigma(I)
$$

$R_{\text {int }}=0.051$

$\theta_{\max }=25.6^{\circ}$

$h=0 \rightarrow 13$

$k=0 \rightarrow 25$

$l=0 \rightarrow 16$
Table 1. Selected geometric parameters $\left(\AA^{\circ},{ }^{\circ}\right)$

$\begin{array}{cccc}\mathrm{O} 11-\mathrm{Cl} & 1.257(2) & \mathrm{S} G 2-\mathrm{S} G 2^{1} & 2.0387(9) \\ \mathrm{O} 21-\mathrm{C} 1 & 1.251(2) & \mathrm{C} 3-\mathrm{O} 13 & 1.2021(19) \\ \mathrm{C} A 2-\mathrm{C} B 2 & 1.543(2) & \mathrm{C} 3-\mathrm{O} 23 & 1.323(2) \\ \mathrm{C} B 2-\mathrm{S} G 2 & 1.8098(19) & & \\ \mathrm{C} A 2-\mathrm{C} B 2-\mathrm{S} G 2 & 114.41(12) & \mathrm{C} B 2-\mathrm{S} G 2-\mathrm{S} G 2^{\circ} & 105.03(6) \\ \mathrm{C} 1-\mathrm{C} 11-\mathrm{N} 2-\mathrm{C} A 2 & & -169.65(14) \\ \mathrm{C} 11-\mathrm{N} 2-\mathrm{C} A 2-\mathrm{C} 2 & & -125.57(16) \\ \mathrm{C} 22-\mathrm{C} B 2-\mathrm{S} G 2-\mathrm{S} G 2^{1} & & -58.30(13) \\ \mathrm{C} B 2-\mathrm{S} G 2-\mathrm{S} G 2^{2}-\mathrm{C} B 2^{1} & & -97.0(4) \\ \mathrm{N} 2-\mathrm{C} A 2-\mathrm{C} 2-\mathrm{N} 3 & & 14.0(2) \\ \mathrm{C} 2-\mathrm{C} 2-\mathrm{N} 3-\mathrm{CA} 3 & & -174.31(14) \\ \mathrm{C} 2-\mathrm{N} 3-\mathrm{CA} 3-\mathrm{C} 3 & & -85.2(2)\end{array}$

Symmetry code: (i) $-x,-y, z$.

$$
\begin{aligned}
& w=1 /\left[\sigma^{2}\left(F_{o}^{2}\right)+(0.0592 P)^{2}\right. \\
& +0.3916 P] \\
& \text { where } P=\left(F_{o}^{2}+2 F_{c}^{2}\right) / 3 \\
& (\Delta / \sigma)_{\max }=0.034 \\
& \Delta \rho_{\max }=0.394 \mathrm{e}^{-3} \\
& \Delta \rho_{\min }=-0.288 \mathrm{e}^{-3} \\
& \text { Extinction correction: none } \\
& \text { Scattering factors from } \\
& \text { International Tables for } \\
& \text { Crystallography (Vol. C) }
\end{aligned}
$$

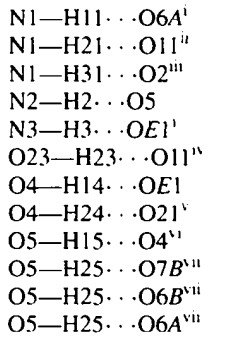

$\begin{array}{llll}0.89 & 2.38 & 3.18(3) & 150 \\ 0.89 & 2.01 & 2.880(2) & 166 \\ 0.89 & 2.08 & 2.844(2) & 144 \\ 0.86 & 2.02 & 2.871(2) & 169 \\ 0.86 & 2.41 & 3.154(2) & 145 \\ 0.97 & 1.74 & 2.6707(18) & 162 \\ 0.950(10) & 1.848(12) & 2.7870(19) & 169\end{array}$

$\begin{array}{llll}0.950(10) & 1.848(12) & 2.7870(19) & 169(3) \\ 0.956(10) & 1.739(11) & 2.691(2) & 173(3)\end{array}$

$0.949(10) \quad 1.845(17) \quad 2.743(2) \quad 157(3)$

$\begin{array}{llll}0.944(10) & 2.05(2) & 2.822(4) & 138(3)\end{array}$

$0.944(10) \quad 2.14(3) \quad 2.840(4) \quad 130(3)$

$0.944(10) \quad 2.65(5) \quad 3.49(4) \quad 149(3)$

Symmetry codes: (i) $1-x,-y, z$; (ii) $-x,-y, z$; (iii) $x, y, 1+z ;$ (iv) $1+x, y, z-1 ;$ (v) $\frac{1}{2}-x, y-\frac{1}{2},-z ;$ (vi) $\frac{1}{2}-x, \frac{1}{2}+y,-z ;$ (vii) $x-\frac{1}{2}, \frac{1}{2}-y,-z$.

The absolute stereochemistry of GSSG is known (L-amino acids) and was thus used to fix the correct enantiomorph for refinement. All the $\mathrm{H}$ atoms could be located in difference Fourier maps, except for those bonded to the two disordered $\mathrm{O} 6$ and $\mathrm{O} 7$ water molecules. The $\mathrm{H}$ atoms of the GSSG molecule were constrained using the $A F I X$ facility of SHELXL97 (Sheldrick, 1997). The water H-atom positions were refined using distance restraints. These disordered water molecules were split into three and two parts, respectively, with the sum of the occupancies restrained to 1 .

Data collection: COLLECT (Nonius, 1998). Cell refinement: DENZO and SCALEPACK (Otwinowski \& Minor, 1997). Data reduction: DENZO and SCALEPACK. Program(s) used to solve structure: SIR92 (Altomare et al., 1994). Program(s) used to refine structure: SHELXL97. Molecular graphics: ORTEP (Johnson, 1970).

We thank Professor Claude Lecomte and Dr Virginie Pichon-Pesme for helpful suggestions.

Supplementary data for this paper are available from the $\mathrm{IUCr}$ electronic archives (Reference: SX1077). Services for accessing these data are described at the back of the journal.

\section{References}

Allen, F. H., Kennard, O., Watson, D. G., Brammer, L., Orpen, A. G. \& Taylor, R. (1987). J. Chem. Soc. Perkin Trans. 2, pp. S1-19.

Altomare, A., Cascarano, G., Giacovazzo, C.. Guagliardi, A., Burla, M. C., Polidori, G. \& Camalli, M. (1994). J. Appl. Crnst. 27, 435. Chaney, M. O. \& Steinrauf, L. K. (1974). Acta Cryst. B30, 711-716.

Cosier, J. \& Glazer, A. M. (1986). J. Appl. Cryst. 19, 105-107.

Görbitz, C. H. (1987). Acta Chem. Scand. Ser. B, 41, 362-366.

Johnson, C. K. (1970). ORTEP. Report ORNL-3794, 2nd revision,

Oak Ridge National Laboratory, Tennessee, USA.

Metzler, D. E. (1977). In Biochemistry. New York: Academic Press.

Nonius (1998). COLLECT. Data Collection Software. Nonius BV, Delft, The Netherlands.

Otwinowski, Z. \& Minor, W. (1997). Processing of X-ray Diffraction Data Collected in Oscillation Mode, Methods in Enzvmology, Vol. 276, edited by C. W. Carter Jr \& R. M. Sweet, Macromolecular Crystallography, Part A, pp. 307-326. New York: Academic Press. Oughton, B. M. \& Harrison, P. M. (1959). Acta Cryst. 12, 396-403. Sheldrick, G. M. (1997). SHELXL97. Program for the Refinement of Crystal Structures. University of Göttingen. Germany.

Wright, W. B. (1958). Acta Cryst. 11, 632.

$\begin{array}{ccccc}D-\mathrm{H} \cdots A & D-\mathrm{H} & \mathrm{H} \cdots A & D \cdots A & D-\mathrm{H} \cdots A \\ \mathrm{~N} 1-\mathrm{H} 11 \cdots \mathrm{O} 6 C^{\mathrm{i}} & 0.89 & 1.89 & 2.750(3) & 162 \\ \mathrm{~N} 1-\mathrm{H} 11 \cdots \mathrm{O} B^{\mathrm{i}} & 0.89 & 2.23 & 2.943(3) & 136 \\ \mathrm{~N} 1-\mathrm{H} 11 \cdots \mathrm{O} C \mathrm{C} & 0.89 & 2.37 & 2.949(3) & 123\end{array}$

